with one another instead of world centres. There is a small oceanographic data centre in existence in Britain at the moment, but this is for bathythermographic data only and it is run by the Ministry of Defence (Navy), Hydrographic Department. The new national centre will cover all oceanographic data from the area of the north-east Atlantic and the North Sea down as far as the bay of Biscay. 'To start with, the centre will collect data on physical oceanography only-temperature, and salinity measurements and so on, but eventually it will store and disseminate information in the whole field of oceanography.

\section{Spina Bifida Appeal}

AN appeal for funds was launched last week by the Spina Bifida Trust (112 City Road, London EC1). Children born with spina bifida, most of whom have hydrocephalus as well, and those with hydrocephalus only, are now surviving in increasing numbers. In Britain there are about 8,000 such children under the age of 16 and their numbers are being added to at the rate of about 900 a year.

Spina bifida is a deformity of the spine in which there is a split in the spinal arch; this causes the nervous tissue to lie exposed on the surface of the back at birth. Some of the nerve cells have not developed properly and the split spine renders them liable to damage, with the result that there is often partial or complete paralysis below the level of the defect. This may affect bladder and bowel control as well as muscles of the limbs.

The development of a valve system for treating hydrocephalus, which occurs in most cases of spina bifida, has made treatment of the rest of the disability worth while. Because of their paralysis the affected children require special education and training. Funds are needed to supply these facilities and to conduct further research into the causes of the condition and its treatment.

\section{Operation Habitat Rescue}

WhDLIFE in agricultural areas is continually threatened as more hedgerows, copses and banks are removed under the pressure of farm mergers, monoculture and more mechanization. To try to reverse the disappearance of wildlife in farming areas in Britain, a Conservation Corps Habitat Rescue is being organized by the Soil Association and the Council for Nature. Young volunteers will try to help the survival of wildlife by conserving hedgerows and banks, ponds and ditches, and planting small copses as refuges. The scheme has been made possible by the Jack and Mary Pye Trust, which is supporting the Soil Association's participation. It is hoped that proper hedge management will not only create and preserve habitats for wildlife but that it will be of direct benefit to farmers in helping conservation of soil fertility and ultimately long-term productivity. In many parts of the country, removal of hedges has led to quite severe soil erosion by wind, in addition to drastic reduction of some species of animals and plants.

Conservation Corps volunteers will work first on the 200 acre experimental farm of the Soil Association in Suffolk. Later, it is planned to extend the work to selected areas of wasteland in other parts of Britain.

\section{Parliament in Britain}

\section{European Technological Collaboration}

Mr A. Wedgwood Benn, Minister of Technology, refused to make available a report of the inter-departmental committee meetings on European Technological Collaboration at the request of $\mathrm{Mr} \mathrm{E}$. Moonman (Billericay). Mr Moonman wanted to know how many meetings of the committee had taken place and urged Mr Benn to make a statement on the future work of the committee. Mr Benn agreed that reports of such committees would be attractive, but suggested that it would make government impossible, and that it would lead to the additional problem of secret meetings of officials to avoid the risk of publication. (Oral answer, March 18.)

\section{Pharmaceutical Products}

Mr E. J. MrLne (Blyth) asked Mr K. Robinson, the Minister of Health, to set up Government-owned factories-preferably in development districts-for the manufacture of drugs, pharmaceuticals and other commodities required by the National Health Service. Disappointed by the minister's negative reply, $\mathrm{Mr}$ Milne stressed the need to look more closely into the matter, adding that pharmaceutical costs "will loom very large in our prices policy in the near future". Also addressing the minister, $\mathrm{Mr}$ Maurice Macmillan (Farnham) asked him if he would bear in mind the record of the pharmaceutical industry which has increased its exports about five times since 1948 and which now stands at a net export figure of about $£ 75$ million. (Oral answer, March 19.)

\section{Medical Computing}

Mr David CROUCH (Canterbury) asked the Minister of Health what plans he had to implement a national plan for medical computing. Mr John Hunt (Bromley) was also interested to know what discussions the minister proposed to have with the computer industry regarding the use of computers both in the medical field and for improving the general administration of the National Health Service. He tried to find out whether the minister could give any indication of the financial savings from the wider use of computers within the Health Service. Mr Robinson replied that discussions were continually being held with computer manufacturers, but he was unable to give any information on Mr Hunt's second point. (Oral answer, March 19.)

\section{Aldermaston}

As usual, Mr Tam Dalyell (West Lothian) had something to say about the type of work done at defence establishments. He tried to ascertain what steps had been taken to declassify work at the Atomic Weapons Research Establishment, Aldermaston, and asked if research for commercial purposes was being promoted there. Mr Benn said that it had always been the practice at Aldermaston to declassify work as far as possible and to publicize the work extensively. $\mathrm{He}$ added that, for the past five years, a large part of the site had been an unclassified area. Dr Jeremy Bray, Joint Parliamentary Secretary to the Minister of Technology, emphasized that the establishment accepts many orders on commercial terms from government departments and from private customers for research and development outside the atomic weapons field. (Oral answer, March 18.) 